\title{
Hubungan Kualitas Air dengan Profil Metabolit Sekunder Ekstrak Daging Holohuria atra di Perairan Teluk Lampung dan Perairan Garut
}

\author{
Relation of Water Quality with Secondary Metabolites Profile of \\ Holothuria atra Flesh Extract in Lampung Bay Waters and Garut Waters \\ Evi Nurfitriani $^{1)}$, Yeni Mulyani' ${ }^{1)}$, M. Untung Kurnia Agung ${ }^{1)}$ \\ ${ }^{1)}$ Fakultas Perikanan dan Ilmu Kelautan Universitas Padjadjaran \\ Jalan Raya Bandung Sumedang KM 21, Jatinangor 45363. \\ Email : evi.nurfiriani2012@gmail.com
}

\begin{abstract}
Abstrak
Penelitian dilakukan untuk mengetahui profil metabolit sekunder teripang Holothuria atra di Perairan Teluk Lampung dan Perairan Garut serta mengetahui hubungan kualitas air pada kedua perairan terhadap kandungan metabolit sekunder teripang Holothuria atra. Pelaksanaan penelitian ini berlangsung dari tanggal 10 Mei 2016 hingga 16 Mei 2016 meliputi pengambilan sampel di Perairan Teluk Lampung dan Perairan Garut serta identifikasi metabolit sekunder di Laboratorium Bioteknologi Kelautan Fakultas Perikanan dan Ilmu Kelautan. Metode penelitian yang digunakan yaitu metode eksploratif dimulai dari pengambilan sampel, pengukuran kualitas air, pengujian metabolit sekunder dan analisis. Pengukuran kualitas air mencakup suhu, salinitas, $\mathrm{pH}$, DO dan kecerahan. Kandungan metabolit sekunder Holothuria atra didapat melalui proses ekstraksi dan identifikasi metabolit sekunder. Hasil penelitian menunjukkan bahwa ekstrak daging Holothuria atra asal Perairan Teluk Lampung mengandung metabolit sekunder alkaloid, flavonoid, steroid dan saponin,, sedangkan Holothuria atra asal Perairan Garut mengandung alkaloid, flavonoid, steroid, triterpen dan saponin.
\end{abstract}

Kata kunci : Holothuria atra, Metabolit Sekunder, Kualitas Air.

\begin{abstract}
The aim of the research to determine secondary metabolites profile of Holothuria atra sea cucumber from Lampung Bay and Garut coastal also the relationship between water quality and their secondary metabolites respectively. This research took place from May $10^{\text {th }} 2016$ to May $16^{\text {th }} 2016$ sampling in Lampung Bay waters and Garut waters and secondary metabolite identification in the laboratory. The method used the explorative method starting from sampling, water quality measurement, testing and analysis of secondary metabolites. Parameter of water quality included temperature, salinity, $\mathrm{pH}, \mathrm{DO}$ and brightness. The content of secondary metabolites Holothuria atra obtained through the extraction process and the identification of it. The results showed that the extract of Holothuria atra from Lampung Bay waters containing alkaloids, flavonoids, steroids and saponins, while the Holothuria atra Garut containing alkaloids, flavonoids, steroids, triterpenes and saponins.
\end{abstract}

Keywords : Holothuria atra, Secondary Metabolites, Water Quality. 


\section{Pendahuluan}

Teripang merupakan kelompok organisme laut dengan pertahanan fisik tidak menonjol, bertubuh lunak dan memiliki pergerakan lambat yang termasuk ke dalam hewan berkulit duri atau Echinodermata. Organisme laut memiliki berbagai mekanisme pertahanan diri untuk bertahan hidup, yaitu secara tingkah laku (kriptik dan nokturnal), fisik (sclerites, pengerasan permukaan tubuh) dan secara kimiawi (chemical defense) dengan menggunakan substansi kimia (Murniasih, 2005). Sebagian besar organisme laut yang bertubuh lunak, pergerakan lambat bahkan tidak bergerak (sesil) dan tidak memiliki sistem pertahanan fisik akan mengembangkan mekanisme pertahanan diri menggunakan substansi kimia. Hal tersebut dilakukan dengan cara memproduksi metabolit sekunder. Teripang sebagai organisme laut menghasilkan senyawa metabolit sekunder sebagai mekanisme pertahanan diri secara kimiawi untuk bertahan dalam lingkungannya (Dyck et al. 2010 dalam Tursina 2011).

Metabolit sekunder adalah senyawa hasil metabolisme yang tidak esensial bagi pertumbuhan organisme yang dihasilkan sebagai interaksinya dengan lingkungan. Menurut Schupp 2000 dalam Tursina 2011, peranan ekologis dari metabolit sekunder pada invertebrata laut perlu diteliti lebih lanjut, terutama sebagai pertahanan kimiawi hewan tersebut. Harper et al. (2001) dalam Murniasih (2005) menyatakan bahwa metabolit sekunder diproduksi oleh organisme sebagai respon terhadap lingkungannya antara lain untuk mencegah bakteri dan radiasi sinar ultraviolet, sebagai antifouling (anti penempelan) serta sebagai pertahanan diri organisme tersebut dari predator.

Kandungan metabolit sekunder pada suatu organisme dipengaruhi beberapa faktor, salah satunya faktor lingkungan. Perairan Teluk Lampung dan Perairan Garut memiliki karakteristik berbeda dilihat dari kondisi perairannya. Perairan Teluk Lampung merupakan perairan tertutup. Menurut Ruswahyuni (2010) perairan tertutup adalah perairan yang terhalang oleh daratan atau pulau di depannya atau berupa teluk, sedangkan Perairan Garut merupakan perairan terbuka. Perairan terbuka adalah suatu daerah perairan yang menghadap ke arah laut lepas tanpa adanya penghalang baik itu pulau maupun daratan di depannya, sangat dipengaruhi oleh ombak dan gelombang. Dari studi literatur di kedua perairan menunjukkan perbedaan pada nilai kualitas air. Kisaran nilai suhu Perairan Garut lebih luas dibandingkan dengan kisaran nilai suhu Perairan Teluk Lampung yaitu $21-31{ }^{\circ} \mathrm{C}$ di Perairan Garut (Shobirin et al. 2013) dan Perairan Teluk Lampung dengan kisaran 28,9-31 ${ }^{\circ} \mathrm{C}$ (Yulianto 2013). Kelarutan oksigen Perairan Garut lebih besar dibanding Perairan Teluk Lampung yaitu 7,67-10,22 mg/1 (Umam 2010) dan DO Perairan Teluk Lampung berkisar antara 4,8-7,3 mg/l (Yulianto 2013). Perairan Teluk Lampung mempunyai nilai $\mathrm{pH}$ yang lebih besar dibandingkan dengan Perairan Garut yaitu 8,02-8,64 (Yulianto, 2013) untuk Perairan Teluk Lampung dan 7,5-8 untuk Perairan Garut (Umam, 2010). Salinitas Perairan Teluk Lampung menunjukkan kisaran 32,50-33,60 psu (Pariwono, 1999), sedangkan untuk Perairan Garut kisaran salinitasnya lebih kecil yaitu 27-31 psu (Umam, 2010). Menurut Shobirin et al. (2013) kecerahan Perairan Garut yaitu 84-100\% dan kecerahan perairan Teluk Lampung 5-16,5 m (Yulianto 2013). Berdasarkan perbedaan kualitas air di kedua lokasi tersebut, maka dilakukan identifikasi kandungan metabolit sekunder teripang Holothuria atra.

\section{Bahan dan Metode}

Penelitian ini dilaksanakan pada 10 Maret 2016 hingga 16 Mei 2016. Pengambilan sampel teripang Holothuria atra dilakukan pada 10 Maret 2016 di Perairan Teluk Lampung dan 6 Mei 2016 di Perairan Garut. Proses ekstraksi dan identifikasi metabolit sekunder secara kualitatif dilakukan di Laboratorium Bioteknologi Perikanan dan Ilmu Kelautan, Gedung 4 Lt. 3, Fakultas Perikanan dan Ilmu Kelautan, Unpad.

Metode yang digunakan yaitu metode eksploratif di laboratorium, data dianalisis secara deskriptif komparatif. Teknik observasi dilakukan untuk mengetahui kualitas air dari habitat teripang. Pengujian metabolit sekunder secara kualitatif meliputi uji alkaloid, flavonoid, steroid dan triterpenoid, fenolik, saponin serta tanin. 


\section{Pengambilan Sampel}

Sampel teripang Holothuria atra diambil dari Perairan Teluk Lampung dan Perairan Garut. Sampel yang didapatkan dikeluarkan organ dalamnya dengan pisau sehingga hanya tersisa dagingnya lalu dicuci dan dimasukkan kedalam kantung plastik. Sampel dimasukkan ke dalam styrofoam yang ditambahkan es batu yang bertujuan sebagai pengawetan sampel selama perjalanan dari lapangan menuju laboratorium.

Saat pengambilan sampel dilakukan juga pengukuran kualitas perairan. Parameter kualitas air yang diamati yaitu suhu, kelarutan oksigen, $\mathrm{pH}$, salinitas dan kecerahan. Sebagai data pendukung diamati juga jenis substrat dan keberadaan predator teripang.

\section{Ekstraksi}

Sampel teripang ditimbang beratnya kemudian dicacah halus. Sampel direndam dengan pelarut metanol absolut dalam erlenmeyer hingga seluruh bagian sampel terendam. Perendaman dilakukan selama 24 jam pada suhu kamar dengan bantuan orbital shaker. Setelah 24 jam perendaman, kemudian dilakukan proses penyariangan, residu direndam kembali dengan metanol selama 24 jam. Proses tersebut dilakukan secara berulang hingga filtrat yang dihasilkan menjadi bening. Filtrat dihitung volumenya kemudian diuapkan menggunakan rotary evaporator pada suhu $45{ }^{\circ} \mathrm{C}$. Ekstrak pekat yang dihasilkan ditimbang beratnya dan dimasukkan ke dalam botol vial.

\section{Identifikasi Kandungan Metaboli Sekunder}

Identifikasi kandungan metabolit sekunder terdiri dari uji alkaloid, uji flavonoid, uji steroid dan triterpenoid, uji fenolik, uji saponin serta uji tanin dengan uji kualitatif fitokimia (reaksi warna dan pengendapan).

a. Uji Alkaloid (Harborne, 1987)

Ekstrak pekat sebanyak 1 gram dilarutkan dalam kloroform kemudian ditambahkan beberapa tetes amoniak $\left(\mathrm{NH}_{4} \mathrm{OH}\right)$. Setelah itu larutan ekstrak disaring dalam tabung reaksi. Ekstrak kloroform dalam tabung reaksi dikocok dengan 10 tetes $\mathrm{H}_{2} \mathrm{SO}_{4} 2 \mathrm{M}$. Lapisan asam yang terbentuk dipisahkan dalam tabung reaksi lain dan ditambah 2 tetes pereaksi meyer. Hasil uji alkoloid yang positif ditunjukkan dengan endapan putih.

b. Uji flavonoid (Harborne, 1987)

Ekstrak sebanyak 1 gram dilarutkan dalam metanol kemudian dibagi menjadi tiga tabung reaksi. Tabung pertama ditambah amil alkohol, $\mathrm{HCl}$ pekat 2 tetes dan ditambah 0,1 gram bubuk $\mathrm{Mg}$. Tabung reaksi kedua ditambah $\mathrm{H}_{2} \mathrm{SO}_{4} 2 \mathrm{~N}$ sebanyak 2 tetes. Tabung terakhir ditambah $\mathrm{NaOH}$ $10 \%$ sebanyak 2 tetes. Ketiga tabung dikocok kuat. Hasil positif ditunjukkan perubahan warna merah, kuning, dan coklat.

c. Uji steroid dan triterpenoid (Harborne, 1987)

Lapisan kloroform dari uji alkaloid diambil sedikit, dimasukan kedalam plat tetes dan biarkan sampai kering. Setelah kering ditambahkan satu tetes asam asetat anhidrida dan satu tetes asam sulfat pekat (Pereaksi Liebermann burchard). Adanya senyawa triterpenoid ditandai dengan terbentuknya warna merah dan adanya senyawa steroid ditandai dengan terbentuknya warna biru atau ungu.

d. Uji fenolik (Harborne, 1987)

Ekstrak sebanyak 1 gram dicampurkan kedalam $20 \mathrm{ml}$ etanol $70 \%$ kemudian dikocok dan diambil $1 \mathrm{ml}$. Setelah diambil $1 \mathrm{ml}$ ditambahkan pereaksi $\mathrm{FeCl}_{3} 5 \%$. Adanya kandungan senyawa fenolik ditandai dengan terbentuknya warna biruungu.

e. Uji saponin (Harborne, 1987)

Sebanyak 1 gram ekstrak dimasukkan kedalam erlenmeyer lalu ditambahkan 10 $\mathrm{ml}$ air panas. Kemudian didihkan selama 5 menit dan saring dalam keadaan panas. Setelah itu kocok dengan kuat secara vertikal selama 10 detik. Adanya saponin ditandai dengan terbentuknya busa yang stabil tidak kurang dari 10 menit setinggi $1-10 \mathrm{~cm}$ dan tidak hilang pada penambahan satu tetes $\mathrm{HCl} 2 \mathrm{~N}$.

f. Uji tanin (Harborne, 1987)

Sebanyak 1 gram ekstrak sampel ditambahkan air, dididihkan selama beberapa menit dan saring, diambil $2 \mathrm{ml}$ hasil penyaringan (filtrat) dan ditambahkan 1 sampai 2 tetes pereaksi $\mathrm{FeCl}_{3}$ 5\%. Hasil positif ditandai dengan terbentuknya warna biru tua atau hijau kehitaman. 
Evi Nurfitriani : Hubungan Kualitas Air dengan Profil Metabolit Sekunder Ekstrak Daging Holohuria atra di Perairan Teluk Lampung dan Perairan Garut

Skoring Kondisi Lingkungan Pengambilan Sampel

Penentuan skor hasil pengukuran kualias air pada Perairan Teluk Lampung dan Perairan Garut dibandingkan dengan kondisi ideal kehidupan teripang (Wibowo et al. dalam Meydia, 2006). Skor yang diberikan yaitu 1 (positif satu) untuk kondisi lingkungan yang sesuai dengan kehidupan teripang dan -1 (minus satu) untuk kondisi lingkungan yang tidak sesuai dari kondisi ideal teripang.

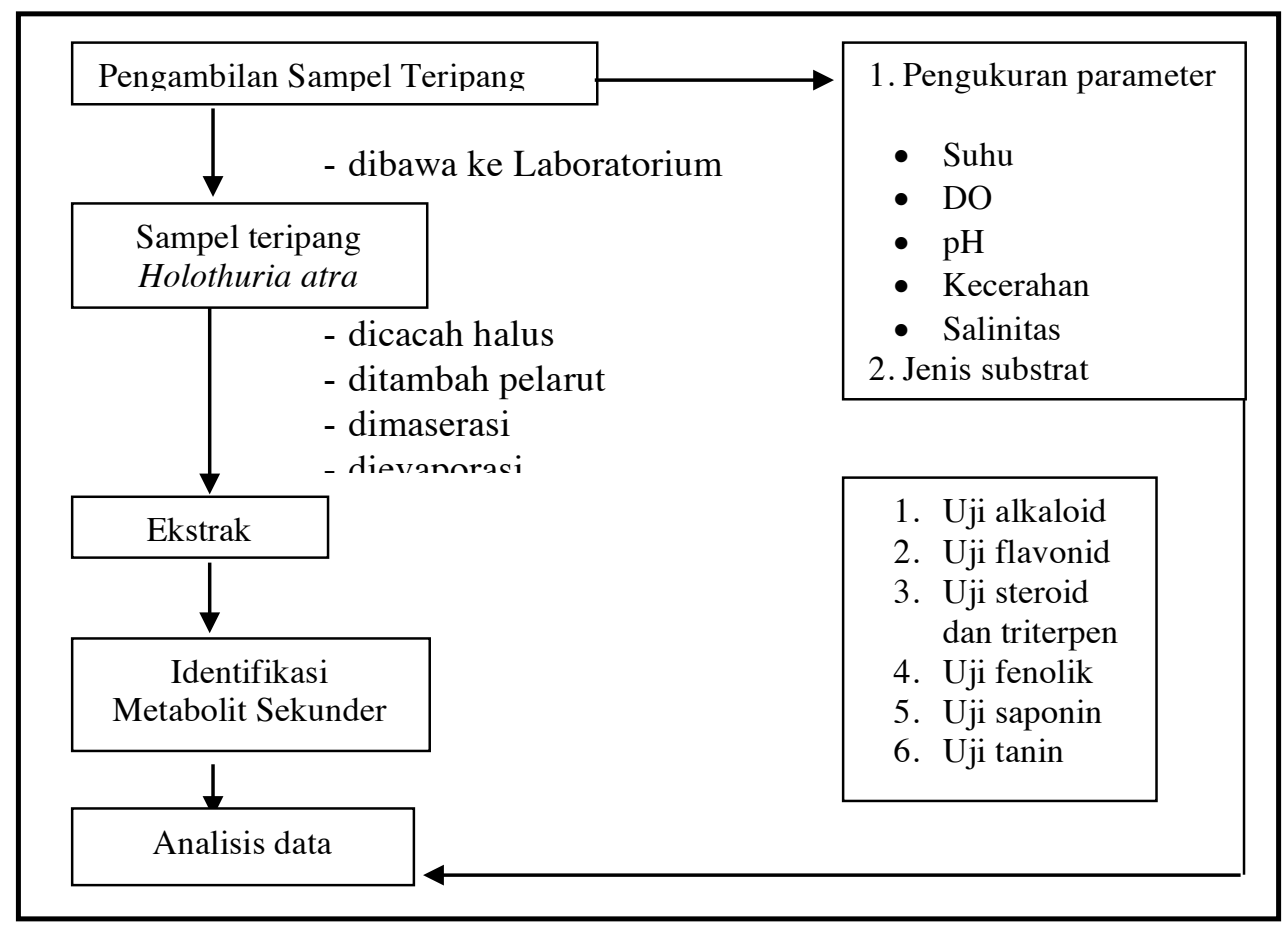

Gambar 1. Alur Penelitian

Figure 1. Research Workflow

\section{Hasil dan Pembahasan}

\section{Pengukuran Kualitas Air}

Dari hasil pengamatan kualitas air pada kedua perairan yaitu perairan Teluk Lampung dan Perairan Garut menunjukkan bahwa beberapa parameter di kedua perairan memiliki nilai kualitas air diatas nilai optimal kehidupan teripang berdasarkan Wibowo et al. dalam Meydia (2006). Namun nilai kualitas air pada kedua perairan masih dibawah ambang batas dari baku mutu air laut untuk biota laut berdasarkan Keputusan Menteri Negara Lingkungan Hidup Nomor 51 Tahun 2004 tentang Baku Mutu Air Laut.

Tabel 1. Perairan Teluk Lampung

Table 1. The Bay of Lampung

\begin{tabular}{ccccccc}
\hline Stasiun & $\begin{array}{c}\text { Kedalaman } \\
(\mathrm{m})\end{array}$ & $\begin{array}{c}\text { Suhu } \\
\left({ }^{\circ} \mathrm{C}\right)\end{array}$ & $\begin{array}{c}\text { DO } \\
(\mathrm{ppm})\end{array}$ & $\mathrm{pH}$ & $\begin{array}{c}\text { Salinitas } \\
(\% \mathrm{o})\end{array}$ & $\begin{array}{c}\text { Kecerahan } \\
(\%)\end{array}$ \\
\hline \multirow{3}{*}{1} & 1,3 & 29,5 & 6,6 & 8,2 & 31,5 & 100 \\
& 1,3 & 30 & 6,8 & 8,4 & 32 & 100 \\
& 1,3 & 29 & 7,4 & 8,5 & 32 & 100 \\
2 & 1,3 & 29 & 6,9 & 8,6 & 32 & 90 \\
& 1,3 & 30,5 & 6,6 & 8,33 & 31,5 & 90 \\
& 1,3 & 29,5 & 7,6 & 8,3 & 32 & 90 \\
\hline
\end{tabular}


Tabel 2. Perairan Garut

Table 2. Garut Seawater

\begin{tabular}{ccccccc}
\hline Stasiun & $\begin{array}{c}\text { Kedalaman } \\
(\mathrm{m})\end{array}$ & $\begin{array}{c}\text { Suhu } \\
\left({ }^{\circ} \mathrm{C}\right)\end{array}$ & $\begin{array}{c}\text { DO } \\
(\mathrm{ppm})\end{array}$ & $\mathrm{pH}$ & $\begin{array}{c}\text { Salinitas } \\
(\%)\end{array}$ & $\begin{array}{c}\text { Kecerahan } \\
(\%)\end{array}$ \\
\hline \multirow{3}{*}{1} & 1 & 31,5 & 10,02 & 8,03 & 28 & 100 \\
& 1 & 31 & 9,7 & 8,02 & 27 & 100 \\
& 1 & 29,5 & 9,1 & 7,8 & 27,5 & 100 \\
2 & 1 & 31,5 & 9,2 & 8,1 & 28 & 100 \\
& 1 & 31,5 & 9,8 & 8,1 & 28 & 100 \\
& 1 & 28 & 8,7 & 7,9 & 27 & 100 \\
\hline
\end{tabular}

\section{Ekstraksi}

Ekstraksi daging teripang Holothuria atra menggunakan metode maserasi dengan teknik tunggal. Maserasi merupakan cara ekstraksi sederhana yang dilakukan dengan cara merendam bahan dalam pelarut selama beberapa hari pada temperatur kamar dan terlindung dari cahaya (Ahmad et al, 2014). Ekstraksi tunggal adalah teknik ekstraksi pada bahan secara langsung menggunakan satu jenis pelarut (Putri, 2013). Sampel daging teripang yang digunakan yaitu sampel basah. Penggunaan sampel basah dilakukan karena lebih praktis dibandingkan dengan sampel kering. Sampel daging teripang yang diekstrak dengan pelarut metanol dengan perbandingan 1:5. Volume pelarut yang banyak akan lebih tersebar merata pada sampel, sehingga seluruh bagian sampel akan terbasahi oleh pelarut dan senyawa yang terkandung dalam sampel akan semakin banyak yang terekstrak.

Tabel 3. Hasil Proses Ekstraksi

Table 3. Result of Extraction Process

\begin{tabular}{ccccccc}
\hline $\begin{array}{c}\text { Sampel } \\
\text { Teripang }\end{array}$ & Stasiun & $\begin{array}{c}\text { Berat awal } \\
\text { sampel (gram) }\end{array}$ & $\begin{array}{c}\text { Volume } \\
\text { filtrat }(\mathrm{mL})\end{array}$ & $\begin{array}{c}\text { Berat } \\
\text { ekstrak } \\
\text { (gram) }\end{array}$ & $\begin{array}{c}\text { Rendemen } \\
(\%)\end{array}$ & $\begin{array}{c}\text { Warna } \\
\text { ekstrak }\end{array}$ \\
\hline $\begin{array}{c}\text { Perairan } \\
\text { Teluk }\end{array}$ & 1 & 300,15 & 4700 & 12,6643 & 4,2193 & Merah tua \\
Lampung & 2 & 300,38 & 4600 & 13,0883 & 4,3572 & Merah tua \\
Perairan & 1 & 299,98 & 4650 & 15,9879 & 5,3293 & Merah tua \\
Garut & 2 & 300,22 & 4550 & 17,6791 & 5,8888 & Merah tua \\
\hline
\end{tabular}

Rendemen yang didapat dari daging teripang yaitu 4,2193-5,8888\%. Rendemen yang didapat menunjukkan banyaknya senyawa metabolit yang terambil dari sampel oleh pelarut. Rendemen dari daging teripang asal Perairan Garut memiliki rendemen yang paling tinggi. Dari nilai rendemen dapat diduga bahwa kandungan metabolit sekunder yang dimiliki teripang Holothuria atra Perairan Garut lebih banyak dibandingkan dengan teripang Perairan Teluk Lampung.

\section{Profil Metabolit Sekunder}

Hasil identifikasi metabolit sekunder menunjukkan bahwa ekstrak daging Holothuria atra Perairan Teluk Lampung mengandung metabolit sekunder alkaloid, flavonoid, steroid dan saponin. Sedangkan ekstrak daging Holothuria atra Perairan Garut mengandung metabolit sekunder alkaloid, flavonoid, steroid dan triterpen serta saponin. 
Evi Nurfitriani : Hubungan Kualitas Air dengan Profil Metabolit Sekunder Ekstrak Daging Holohuria atra di Perairan Teluk Lampung dan Perairan Garut

Tabel 4. Profil Metabolit Sekunder

Table 4. Secondary Metabolites Profile

\begin{tabular}{|c|c|c|c|c|c|}
\hline \multicolumn{2}{|c|}{ Metabolit Sekunder } & \multicolumn{2}{|c|}{$\begin{array}{l}\text { Ekstrak Daging H.atra } \\
\text { Perairan Teluk Lampung }\end{array}$} & \multicolumn{2}{|c|}{$\begin{array}{c}\text { Ekstrak Daging H.atra } \\
\text { Perairan Garut }\end{array}$} \\
\hline & & Stasiun 1 & Stasiun 2 & Stasiun 1 & Stasiun 2 \\
\hline \multirow[t]{2}{*}{ Alkaloid } & Meyer & + & + & + & + \\
\hline & Dragendrof & + & + & + & + \\
\hline \multirow{3}{*}{ Flavonoid } & $\mathrm{HCl}$ & + & + & + & + \\
\hline & $\mathrm{H}_{2} \mathrm{SO}_{4}$ & + & + & + & + \\
\hline & $\mathrm{NaOH}$ & - & - & - & - \\
\hline Steroid & & + & + & + & + \\
\hline Triterpen & & - & - & + & + \\
\hline Fenolik & & - & - & - & - \\
\hline Saponin & & + & + & + & + \\
\hline Tanin & & - & - & - & - \\
\hline
\end{tabular}

\section{Profil Morfologi dan Fisiologi}

Teripang Holothuria atra yang didapat diidentifikasi berdasarkan buku Panduan Lapangan Identifikasi Ikan-ikan Karang dan Invertebrata (Setyawan 2010) dan Jaeger (1833) dalam Tehranifard (2012). Berdasarkan morfologi, teripang Holothuria atra yang ditemukan pada kedua perairan cukup memiliki perbedaan. Pada Perairan
Teluk Lampung teripang Holothuria atra ditemukan dalam ukuran yang besar dan panjang dengan kisaran 21-24 cm dan keberadaanya ada di daerah lamun. Sedangkan pada Perairan Garut teripang Holothuria atra yang ditemukan memiliki ukuran yang lebih kecil dibanding teripang Holothuria atra dari Perairan Teluk Lampung, dengan kisaran 18-21 cm dan keberadaaanya ada di sela-sela batu.

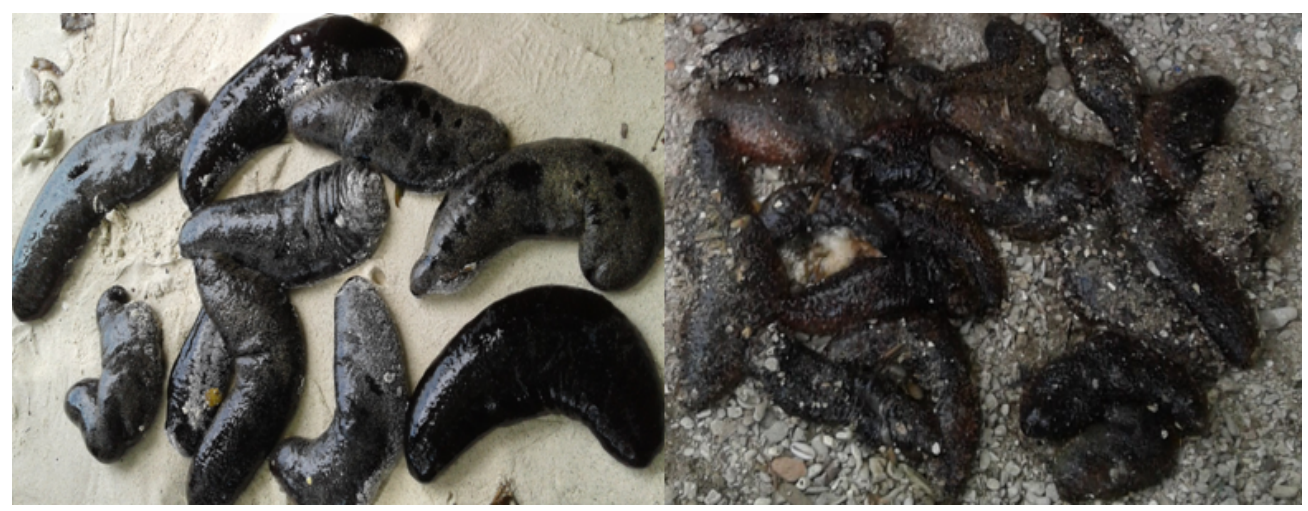

A. Perairan Teluk Lampung

B. Perairan Garut

Gambar 1. Perbedaan Ukuran Tubuh Holothuria atra Kedua Perairan Sumber : (Dokumentasi Pribadi)

Picture 1. Body Size Differences Holothuria atra from Both Seawater Source : (Personal Documentation)

Keberadaan teripang Holothuria atra saat pengambilan sampel di Perairan Garut berada di sela-sela karang dan beberapa membenamkan diri, hal ini diduga karena Perairan Garut memiliki suhu yang tinggi sehingga teripang melakukan mekanisme pertahanan dirinya dengan bersembunyi di sela-sela karang. Sedangkan teripang Holothuria atra yang ditemukan di Perairan
Teluk Lampung rata-rata tubuhnya dilapisi pasir di daerah lamun. Menurut Aziz (1995) kebiasaan teripang melapisi tubuhnya dengan selapis pasir halus berkaitan dengan upaya meredam pengaruh intensitas cahaya yang kuat dan menghindari suhu yang relatif tinggi di waktu siang serta teripang yang membenamkan diri untuk tujuan yang sama. 
Saat diangkat dari perairan, teripang Holothuria atra pada perairan ini memiliki tube feet pada tubuhnya yang lebih terasa dipegang dibanding dengan Holothuria atra Perairan Teluk Lampung yang tubuhnya cenderung halus. Selain itu, pada saat pengambilan sampel teripang Holothuria atra di kedua perairan diantaranya mengeluarkan cairan berwarna merah. Hal ini sesuai dengan
Aziz (1995) bahwa teripang jenis Holothuria atra melakukan pertahanan diri dengan mengeluarkan carian berwarna merah yang diduga senyawa holothurin saat mendapat gangguan. Senyawa ini dapat digunakan juga oleh teripang untuk menghadapi predator. Dari hasil pengamatan, kedua perairan terdapat predator teripang.

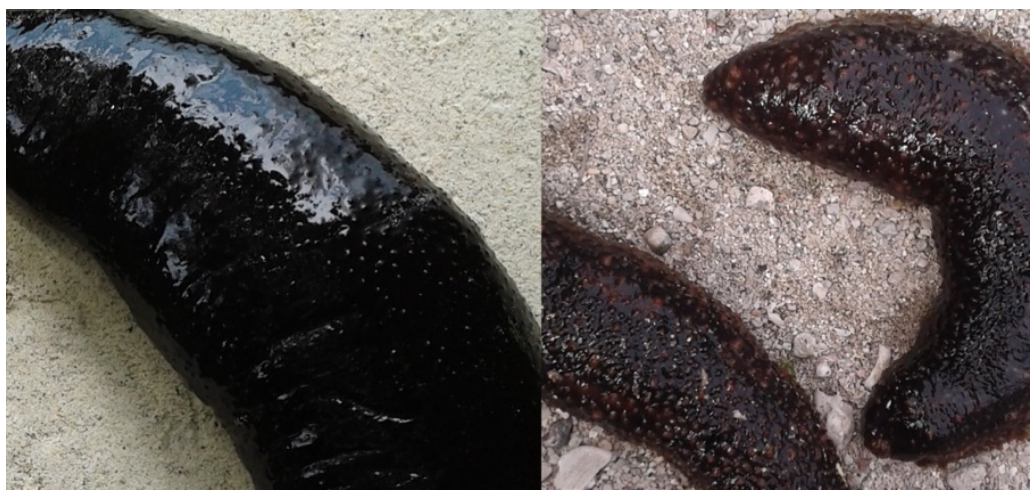

A. Perairan Teluk Lampung $\quad$ B. Perairan Garut

Gambar 2. Perbedaan Morfologi Holothuria atra Kedua Perairan Sumber : (Dokumentasi Pribadi)

Picture 3. Morphology differences Holothuria atra from Both Seawater Source : (Personal Documentation)
Hubungan Kualitas Air dengan Profil Metabolit Sekunder

Dari hasil pengukuran kualitas air, Perairan Garut dapat dikatakan lebih memicu keadaan stres bagi teripang karena kondisi perairannya yang cenderung dinamis dengan ombak yang besar. Kondisi ini yang memungkinkan kandungan metabolit sekunder yang dihasilkan teripang Holothuria atra Perairan Garut lebih beragam dibanding dengan teripang periaran Teluk Lampung. Meskipun metabolit sekunder secara kualitatif menunjukan hasil yang tidak jauh berbeda, namun pada daging teripang Holothuria atra Perairan Teluk Lampung tidak memiliki senyawa triterpenoid.

Tabel 5. Skoring Kondisi Lingkungan

Table 5. Scoring of Environmental Condition

\begin{tabular}{|c|c|c|c|c|c|c|c|c|c|}
\hline \multirow{3}{*}{ Parameter } & \multirow{3}{*}{$\begin{array}{c}\text { Ideal } \\
\text { teripang }\end{array}$} & \multicolumn{4}{|c|}{ Hasil pengukuran } & \multicolumn{4}{|c|}{ Skoring } \\
\hline & & \multicolumn{2}{|c|}{$\begin{array}{c}\text { Teluk } \\
\text { Lampung }\end{array}$} & \multicolumn{2}{|c|}{ Garut } & \multicolumn{2}{|c|}{$\begin{array}{c}\text { Teluk } \\
\text { Lampung }\end{array}$} & \multicolumn{2}{|c|}{ Garut } \\
\hline & & St 1 & St 2 & St 1 & St 2 & St 1 & St 2 & St 1 & St 2 \\
\hline Suhu $\left({ }^{\circ} \mathrm{C}\right)$ & $20-25$ & $29-30$ & $29-30,5$ & $29,5-31,5$ & $28-31,5$ & -1 & -1 & -1 & -1 \\
\hline DO (ppm) & $4-8$ & $6,6-7,4$ & $6,6-7,6$ & $9,1-10,02$ & $8,7-9,8$ & 1 & 1 & -1 & -1 \\
\hline $\mathrm{pH}$ & $6,5-8,5$ & $8,2-8,5$ & $8,3-8,6$ & $7,8-8,03$ & $7,9-8,1$ & 1 & -1 & 1 & 1 \\
\hline $\begin{array}{l}\text { Salinitas } \\
\text { (psu) }\end{array}$ & $29-33$ & $31,5-32$ & $31,5-32$ & $27-28$ & $27-28$ & 1 & 1 & -1 & -1 \\
\hline $\begin{array}{l}\text { Kecerahan } \\
(\%)\end{array}$ & Jernih & 100 & 90 & 100 & 100 & 1 & 1 & 1 & 1 \\
\hline \multicolumn{6}{|c|}{ Jumlah } & 3 & 1 & -1 & -1 \\
\hline
\end{tabular}

Berdasarkan Tabel 5 menunjukkan kesesuaian kondisi lingkungan dengan kehidupan teripang. Dari tabel skoring dapat dilihat bahwa dua stasiun di Perairan Teluk Lampung mempunyai nilai akhir positif, sedangkan dua stasiun di Perairan Garut 
Evi Nurfitriani : Hubungan Kualitas Air dengan Profil Metabolit Sekunder Ekstrak Daging Holohuria atra di Perairan Teluk Lampung dan Perairan Garut

mempunyai nilai akhir negatif. Hal ini menunjukkan bahwa kondisi stres lingkungan kehidupan teripang Perairan Garut lebih tinggi dibandingkan Perairan Teluk Lampung.
Kondisi stres Perairan Garut dapat dilihat pada nilai rendemen yang didapat dan hasil identifikasi metabolit sekunder serta data ukuran tubuh pada Tabel 6 .

Tabel 6. Hubungan Skoring Lingkungan dengan Hasil Uji dan Pengukuran Table 6. Relation of Environmental Scoring with Test Result and Measurements

\begin{tabular}{|c|c|c|c|c|c|}
\hline \multirow{2}{*}{ No. } & \multirow{2}{*}{ Parameter } & \multicolumn{2}{|c|}{ Teluk Lampung } & \multicolumn{2}{|c|}{ Garut } \\
\hline & & St 1 & St 2 & St 1 & St 2 \\
\hline 1 & Skoring lingkungan & 3 & 1 & -1 & -1 \\
\hline 2 & Ukuran tubuh $(\mathrm{cm})$ & $21-24,5 \mathrm{~cm}$ & $21-24,5 \mathrm{~cm}$ & $18-21 \mathrm{~cm}$ & $18-21 \mathrm{~cm}$ \\
\hline \multirow{6}{*}{3} & & 4 Jenis : & 4 Jenis : & 5 Jenis : & 5 Jenis : \\
\hline & & - Alkaloid & - Alkaloid & - Alkaloid & - Alkaloid \\
\hline & Jenis metabolit & - Flavonoid & - Flavonoid & - Flavonoid & - Flavonoid \\
\hline & sekunder & - Steroid & - Steroid & - Steroid & - Steroid \\
\hline & & - Saponin & - Saponin & - Triterpen & - Triterpen \\
\hline & & & & - Saponin & - Saponin \\
\hline 4 & Rendemen $(\%)$ & 4,2193 & 4,3572 & 5,3293 & 5,8888 \\
\hline
\end{tabular}

Stres Lingkungan Perairan Garut dapat terlihat dari ukuran tubuh teripang Holothuria atra yang ditemukan pada perairan ini relatif lebih kecil. Menurut Dalimonthe (1987) kondisi stres lingkungan menguntungkan produksi metabolit sekunder, namun kondisi stres lingkungan dapat mengurangi pertumbuhan sel organisme hal ini dapat dilihat dari ukuran tubuh teripang. Teripang Holothuria atra pada Perairan Teluk Lampung ditemukan dalam ukuran yang besar hal ini diduga karena perairan ini merupakan perairan yang tenang sehingga pertumbuhan teripang tidak terhambat sedangkan teripang Holothuria atra pada Perairan Garut ditemukan dalam ukuran yang kecil, hal ini diduga karena Perairan Garut memiliki kondisi perairan yang dinamis dengan ombak besar sehingga menghambat pertumbuhan teripang. Selain itu, stres lingkungan Perairan Garut memungkinkan kandungan metabolit sekunder yang terkandung dalam daging teripang lebih bervariasi dibandingkan dengan Perairan Teluk Lampung meskipun metabolit sekunder secara kualitatif menunjukan hasil yang tidak jauh berbeda, namun pada daging teripang Holothuria atra Perairan Teluk Lampung tidak memiliki senyawa triterpenoid. Hal ini juga ditunjukkan dengan nilai rendemen yang didapat pada ekstrak daging Perairan Garut lebih tinggi hal ini diduga karena metabolit sekunder yang diproduksi untuk pertahanan diri dari kondisi dengan tekanan oleh teripang Holothuria atra di Perairan Garut lebih banyak

\section{Simpulan}

Berdasarkan penelitian dapat disimpulkan bahwa ektrak daging Holothuria atra Perairan Teluk Lampung mengandung metabolit sekunder alkaloid, flavonoid, steroid dan saponin, sedangkan ekstrak daging Holothuria atra Perairan Garut mengandung alkaloid, flavonoid, steroid dan triterpen serta saponin. Adapun pengaruh dari kualitas air terhadap kandungan metabolit sekunder teripang Holothuria atra pada Perairan Garut menghasilkan metabolit sekunder yang lebih beragam dengan terkandungnya metabolit sekunder golongan triterpenoid.

\section{Saran}

Berdasarkan pada penelitian yang telah dilakukan, disarankan perlunya pengkajian yang lebih mendalam mengenai kandungan metabolit sekunder teripang Holothuria atra diantaranya perlu dilakukan pengujian kuantitas metabolit sekunder dan pengujian bioaktivitas.

\section{Daftar Pustaka}

Ahmad, D., et al. 2014. Ekstraksi Minyak Atsiri Mahkota Bunga Mawar (Rosa hybrid L.) dengan Metode Maserasi. Universitas Pendidikan Indonesia. 
Aziz, A. 1995. Beberapa Catatan tentang Teripang Bangsa Aspidochirotida. Oseana 20 (4) : 11-23.

Dalimonthe, S. L. 1987. Kultur Jaringan sebagai Sarana untuk Menghasilkan Metabolit Sekunder. Dalam: Suwijiyo, p., Gunawan, D., dan Soegihardjo, C. J. (Ed), Buku Risalah Seminar Nasional Metabolit Sekunder. 6-9 September 1987, Yogyakarta, PAU Bioteknologi UGM. Hlm. 157-162.

Harborne, J.B. 1987. Metode Fitokimia Penuntun Cara Modern Menganalisis Tumbuhan. Universitas Reading. Penerbit ITB. Bandung.

Murniasih, T. 2005. Substansi Kimia Untuk Pertahanan Diri dari Hewan Laut tak Bertulang Belakang. Oseana 30 (2) : 19-27.

Setiawan, F. 2010. Panduan Lapangan Identifikasi Ikan Karang dan Invertebrata Laut. Wildlife Conservation Society, Manado.

Shobirin, M. R., et al. Studi Kelayakan Perairan untuk Pengembangan
Budidaya Abalon (Haliotis asinina) di Perairan Sayang Heulang, Pameungpeuk, Garut. Jurnal Perikanan Kelautan 4 (4) : 445-452.

Tehranifard, A., Rahimibashar, M. R. 2012. Description a Sea Cucumber Spesies Holothuria atra Jaeger, 1833 from Kiss Island Iran (Echinodermata: Holothuridea). Journal of Basic and Applied Scientific Research 2 (12) : 12660-12662.

Tursina, L. M. 2011. Uji Antifeedant Ekstrak Kasar Teripang Holothuria atra dan Bohadschia marmorata terhadap Ikan Karang di Perairan Pulau Pramuka, Kepulauan Seribu, DKI Jakarta. Skripsi. Fakultas Matematika dan Ilmu Pengetahuan Alam. Universitas Indonesia. Depok.

Widodo, A. 2013. Budidaya Teripang. Yogyakarta: Pustaka Baru Press. Hal. 1-19.

Yulianto, H. 2013. Pemetaan Sebaran Spasial Kualitas Air Unsur Hara Perairan Teluk Lampung. Aquasains (Jurnal Ilmu Perikanan dan Sumberdaya Perairan) 2 (1). 